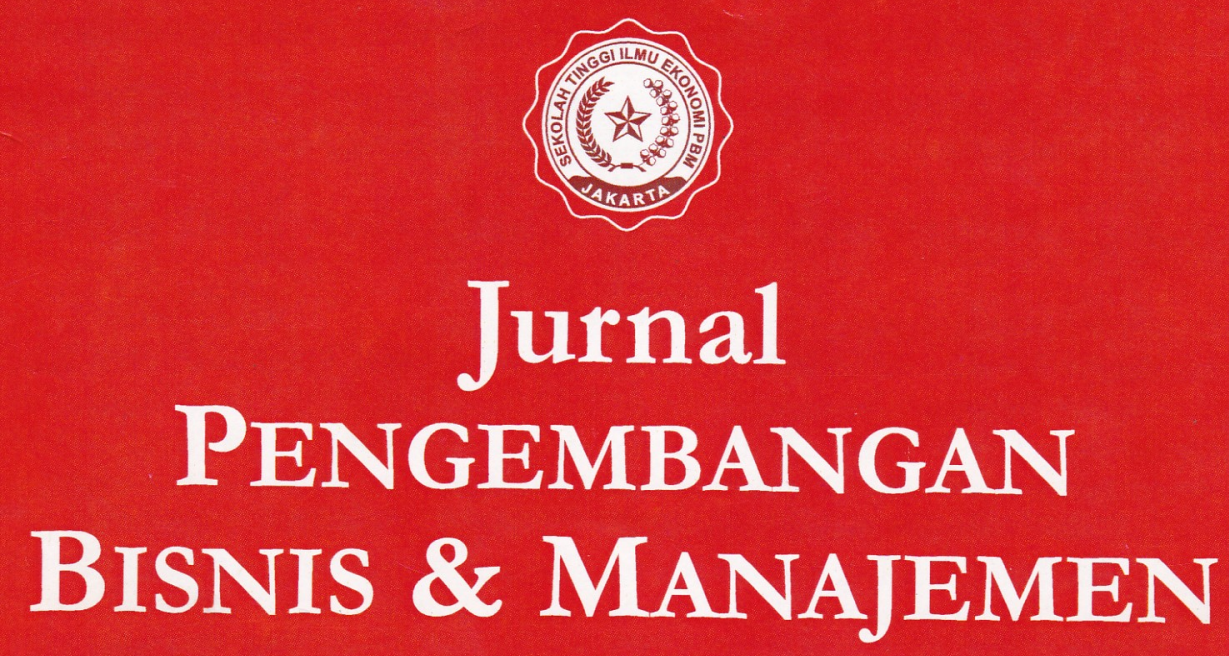

ANALISIS KEBUTUHAN BERAS DAERAH DI INDONESIA ( STUDI KASUS : 2009 DAN 2014) Yoewono Hadisupadmo

KELEMBAGAAN PROGRAM KAWASAN TERPADU DALAM MENDUKUNG PROGRAM PEMBANGUNAN DAERAH TERTINGGAL

Sasli Rais

STRATEGI MEMACU MOTIVASI MELALUI "SELF MANAGEMENT" Djano Lastro

PENGARUH MOTIVASI TERHADAP KINERJA PEGAWAI PT. JASA MARGA (PERSERO) TBK (Studi Kasus pada Gerbang Tol Cikarang Utama) Wakhyudin \& Fauziah Afriyani

ANALISIS RASIO KEUANGAN SEBAGAI ALAT PENILAI KINERJA KEUANGAN PADA PT. UNILEVER INDONESIA, TBK TAHUN 2012-2014

Neli Marita \& Eni Winarti

MEMBENTUK ORGANISASI MULTIKULTURAL DALAM ERA GLOBALISASI Hotner Tampubolon

MEMBUAT RAMALAN KUANTITATIF DENGAN MENGGUNAKAN TIME SERIES DATA

Windarko

PENGARUH PENGEMBANGAN SDM DAN KEPEMIMPINAN TERHADAP KINERJA KARYAWAN PADA BADAN PENELITIAN DAN PENGEMBANGAN (BPP) KEMENTRIAN DALAM NEGERI Sutar

PENGARUH PEMASARAN TERHADAP PEROLEHAN DANA TABUNGAN PADA PT. BANK MANDIRI (PERSERO) TBK. 


\title{
PENGARUH PENGEMBANGAN SDM DAN KEPEMIMPINAN TERHADAP KINERJA KARYAWAN PADA BADAN PENELITIAN DAN PENGEMBANGAN (BPP) KEMENTRIAN DALAM NEGERI
}

\author{
Sutar $V$ \\ Manajemen, STIE Muhammadiyah Jakarta \\ E-mail :sutarse09@gmail.com
}

\begin{abstract}
:
The development of Human Resources ( HR ), human beings can not be separated from other activities such as strategic planning, management development and organizational development. The role of HR in the organization has the same meaning as important as the work itself, so that the interaction between the organization and the focus of attention of HR leaders. An organization will be able to grow and reach the height of glory if it has qualified human resources. Training and human resource development becomes a necessity for organizations, because employees direct placement in a job does not guarantee they will succeed. This study examines the development of human resources and the leadership to employee performance. The study looked at the effect of the development of human resources and leadership to the employee performance. Research methodology forget explanatory research that describes the influence of independent variables on the dependent variable with the goal of research is BPP Kemendagri Jakarta with a sample of 78 employees. Results showed as partial the development of Human resources and leadership significantly influence the employee performance. simultaneously both development human resources and leadership training variables jointly significant effect on the employee performance.
\end{abstract}

Keywords: The development of Human Resources, leadership, the cmployee performance.

\section{Pendahuluan}

Sumber Daya Manusia (SDM) merupakan potensi yang ada dalam diri manusia untuk mewujudkan perannya sebagai mahluk social yang adaftif dan transformative yang mampu mengelola dirinya sendiri serta seluruh potensi yang terkandung di dalamnya menuju tercapainya kesejahteraan kehidupan dalam tatanan yang seimbang dan berkelanjutan. (Hamalik, 2011)

Kejelasan visi dan misi organisasi merupakan prasyarat bagi keberhasilan suatu organisasi. Aspek kompetensi menunjukkan bahwa perhatian organisasi lebih difokuskan kepada kompetensi SDM. Jika kita menggunakan SDM sebagai faktor penentu organisasi, maka kompetensi menjadi aspek yang menentukan keberhasilan organisasi.

Penanganan masalah-masalah SDM seperti rekrutmen dan pelatihan, penghargaan dan pengembangan pribadi, masalah kedisiplinan, ketidakpuasan, dan sebagainya tentu saja berbeda-beda antara organisasi. Namun demikian, para 
pemimpin sudah pasti akan berurusan dengan semua permasalahan diatas, baik dalam taraf yang besar maupun kecil, informal maupun formal, secara pribadi maupun dalam hubungannya dengan yang lain. Sementara itu mendapatkan SDM (orang-orang yang tepat) dan mempekerjakan mereka dengan seefektif mungkin adalah masalah penting yang harus dipertimbangkan apabila sebuah organisasi menginginkan semua kebutuhannya terpenuhi sebagaimana mestinya.

Pengembangan

SDM menunjukkan dunia kerja masa kini dan yang akan datang tentu sangat berbeda, apalagi di era globalisasi.. Peran SDM dalam organisasi mempunyai arti yang sama pentingnya dengan pekerjaan itu sendiri, sehingga interaksi antara organisasi dan SDM menjadi fokus perhatian para pemimpin. Oleh sebab itu nilai-nilai (values) baru yang sesuai dengan tuntutan lingkungan organisasi perlu diperkenalkan dan disosialisasikan kepada semua individu di dalam organisasi. Tujuan pengembangan sumber daya manusia menurut (Martoyo dalam Sudayat, 2011 ) adalah dapat ditingkatkannya kemampuan, keterampilan dan sikap karyawan/anggota organisasi sehingga lebih efektif dan efisien dalam mencapai sasaran-sasaran program ataupun tujuan organisasi. Menurut Manullang (1980) (dalam Sudayat, 2011), tujuan pengembangan pegawai sebenarnya sama dengan tujuan latihan pegawai. Sesungguhnya tujuan latihan atau tujuan pengembangan pegawai yang efektif, untuk memperoleh tiga hal yaitu : 1). menambah pengetahuan; 2). menambah ketrampilan; 3). merubah sikap.

Pendidikan dan pelatihan merupakan suatu upaya yang dilakukan oleh institusi atau organisasi dalam rangka meningkatkan potensi dan kemampuan yang dimiliki oleh pegawai. Oleh sebab itu, pusat pendidikan dan pelatihan disetiap institusi tugas pokoknya adalah melaksanakan pendidikan dan pelatihan pegawai untuk lebih meningkatkan kemampuan pegawai atau karyawan dilingkungan institusi tersebut dan akhirnya juga membawa dampak terhadap pengembangan organisasi atau institusi yang bersangkutan.

Sumber daya manusia adalah merupakan aset organisasi yang paling penting dan membuat sumber organisasi lainnya bekerja. Sumber daya manusia penting karena mempengaruhi efisiensi dan efektivitas organisasi serta merupakan aset perusahaan dalam menjalankan bisnis ( Simamora.2010).

Kemajuan pengetahuan dan perkembangan tehnologi yang begitu pesat pada era 1990-an telah memacu penggunaan peralatan modern dimana sumber daya manusia harus dapat menyesuaikan diri dengan meningkatkan keterampilan dan kemampuannya secara terus menerus sebagai antipasi terhadap peningkatan tuntutan tugas. Menurut Oemar Hamalik ( 2011) "Dimensi pendidikan dan pelatihan memegang peranan penting dalam mengembangkan kualitas manusia Indonesia yang seutuhnya dan menciptakan kesempatan baru untuk tumbuh dan berkembang.

Pelatihan merupakan suatu proses pendidikan untuk jangka pendek dengan menggunakan prosedur pelatihan yang sistematis dan teroganisir sehingga pegawai dapat belajar pengetahuan teknik pengajaran dan keahlian untuk tujuan tertentu (Hasibuan 2002:70).

Penelitian-penelitian dan teori-teori kepemimpinan dapat diklasifikasikan 
sebagai pendekatan-pendekatan kesifatan, perilaku dan situasional (contingency) dalam studi tentang kepemimpinan. Pendekatan pertama memandang kepemimpinan sebagai suatu kombinasi sifat-sifat yang tampak. Seorang pemimpin memiliki ciri-ciri atau sifat-sifat tertentu yang menyebabkan mereka dapat memimpin para pengikutnya. Sifat-sifat ini mencakup energi, pandangan, pengetahuan dan kecerdasan, imajinasi, kepercayaan diri, integritas, kepandaian berbicara, pengendalian dan keseimbangan mental maupun emosional, bentuk fisik, pergaulan sosial dan persahabatan, dorongan, antusiasme, berani dan lain-lain.

Program pelatihan dan pengembangan (training) bertujuan untuk memperbaiki penguasaan berbagai ketrampilan dan tehnik pelaksanaan kerja tertentu sedangkan untuk pengembangan bertujuan untuk menyiapkan pegawainya siap memangku jabatan tertentu dimasa yang akan datang (Husein Umar, 2008).

\section{Sumber Daya Manusia yang} berkualitas adalah sumber daya manusia yang memiliki keahlian, profesionalitas, produktif serta mampu secara mandiri bersaing dengan sehat di dunia kerja. Saat ini tidak hanya sekedar itu saja yang dibutuhkan, akan tetapi lebih dari itu, yaitu Sumber Daya Manusia yang mempunyai wawasan tentang lingkungan. Pembangunan Sumber Daya Manusia mempunyai peran yang sangat penting dalam mewujudkan manusia Indonesia yang maju dan mandiri sehingga mampu berdaya saing dalam era globalisasi.

\section{Tujuan penelitian.}

Penelitian ini bertujuan untuk mengetahui :

1. Seberapa besar Pengaruh Pengembangan SDM terhadap kinerja karyawan. .
2. Seberapa besar
$\begin{aligned} & \text { kepemimpinan } \\ & \text { karyawan. }\end{aligned}$

3. Seberapa besar pengaruh pengembangan SDM dan kepemimpinan secara bersama-sama berpengaruh terhadap kinerja karyawan.

\section{Kajian teori.}

\section{Pengembangan SDM.}

Menurut Andrew E. Sikula pengembangan adalah merupakan satu proses pendidikan jangka panjang yang menggunakan prosedur sistematis dan terorganisasi, pegawai manajerialnya mempelajari pengetahuan konseptual dan teoritis untuk mencapai tujuan umum. Pengembangan sumber daya manusia mengandung tugas untuk mendayagunakan sumber daya manusia yang dimiliki oleh suatu lembaga secara optimal, sehingga sumber daya manusia dapat bekerja secara maksimal untuk bersama-sama mencapai tujuan sesuai dengan visi dan misi organisasi.

Sumber daya manusia adalah merupakan aset organisasi yang paling penting dan membuat sumber organisasi lainnya bekerja. Sumber daya manusia penting karena mempengaruhi efisiensi dan efektivitas organisasi serta merupakan aset perusahaan dalam menjalankan bisnis ( Simamora.2010).

Nawawi 2010, berpendapat Sumber daya manusia adalah potensi dan merupakan aset dan berfungsi sebagai modal (non material/non finansial) di dalam organisasi, yang diwujudkan menjadi potensi nyata secara fisik dan non fisik dalam mewujudkan eksistensi organisasi. 
Menurut Suprihanto (2008) pendidikan dan pelatihan adalah suatu proses pembinaan pengertian dan pengetahuan terhadap kelompok fakta, aturan serta metode yang terorganisasikan dengan mengutamakan pembinaan, kejujuran dan ketrampilan. Berdasarkan definisi tersebut pelakasanaan pendidikan dan pelatihan menitik beratkan pada :

1. Membantu pegawai dalam menambah pengetahuan dan ketrampilan.

2. Pengetahuan dan ketrampilan tersebut sangat erat hubungannya dengan pekerjaan sekarang ataupun masa yang akan datang.

3. Pelaksanaan pendidikan dan pelatihan haruslah direncanakan dan diorganisasikan untuk mendapatkan efektivitas dalam pelaksanaan pendidikan dan latihan itu sendiri.

Martha Monroza Siagian, ( 2010 ) meneliti Pengaruh Pendidikan dan Pelatihan Terhadap Kinerja Pegawai Pada Dinas Tenaga Kerja Kota Medan. Hasil penelitian tersebut diperoleh kesimpulan bahwa pendidikan dan pelatihan mempunyai pengaruh yang positif terhadap kinerja pegawai dan pengaruhnya berada pada kategori sedang. Hal ini terbukti dari hasil perhitungan koefisien korelasi product moment sebesar 5,6. Hal ini menunjukkan bahwa ada pengaruh antara pendidikan dan pelatihan terhadap kinerja pegawai.

Elfina Marlia, (2007) meneliti Pengaruh program pendidikan dan pelatihan terhadap prestasi kerja karyawan pada PT. inti Persero Bandung.

Metode pelatihan harus didasarkan kepada kebutuhan pekerjaan tergantung sebagai faktor, yaitu waktu, biaya, jumlah peserta, tingkat pendidikan dasar peserta, latar belakang peserta dan lain-lain.
Menurut Cherrington (2000:358), dikatakan bahwa metode dalam pelatihan dibagi menjadi dua yaitu on the job traming dan off the job training. On the job training lebih banyak digunakan dibandingkan dengan off the job training.

\section{Tujuan Pelatihan dan Jenis-Jenis Pelatihan}

Menurut Manullang (2000:85) tujuan utama dari pada pelatihan adalah agar pengawasan lebih sedikit bilamana pegawai mendapatkan pendidikan khusus dalam melaksanakan tugas akan cepat berkembang.

Berdasarkan asumsi tersebut dapat diartikan bahwa pelatihan atau instruktur yaitu seorang atau tim yang memberikan pelatihan atau pendidikan kepada para pegawai. Pelatihan (Trainer) memberikan peranan penting terhadap kemajuan kemampuan para pegawai yang akan dikembangkan. Pelatihan yang bertujuan untuk meningkatkan kemapuan pegawai bersifat pelatihan internal eksternal serta gabungan internal dan eksternal.

\section{Pengertian Kepemimpinan}

Kepemimpinan adalah Hubungan yang erat antara seseorang dengan kelompok Manusia karena ada kepentingan yang sama (Ada Pemimpin dan ada yang Dipimpin) (Anonim, 2003) juga bisa diartikan adalah suatu seni dan teknik atau kemampuan untuk membuat sekelompok orang-orang mengikuti atau membuat segala apa yang dikehendaki dan membuat mereka antusias mengikutinya.

Taylor (dalam Drafke, 2009: 460) menjelaskan bahwa kepemimpinan adalah "the ability to influence the activities of others, through the process of communication, toward the attainment of goal." Maknanya kepemimpinan adalah 
kemampuan untuk mempengaruhi aktivitas orang lain melalui proses komunikasi ke arah pencapain tujuan. Definisi yang hampir sama dikemukakan oleh Kinicki dan Kreitner (2008: 479), yaitu: "leadership is the ability influence people toward te attainment of goals." Kepemimpinan adalah kemampuan untuk mempengaruhi orang ke arah pencapaian tujuan organisasi.

Bennis (dalam Parker dan Begnaud, 2004: 3) mengartikan kepemimpinan sebagai "the energetic process of getting other people fully and willingly commited to a course of action, to meet commonly agreed objectives." Pengertian ini bermakna bahwa kepemimpinan adalah proses energik mendapatkan kesungguhan dan kesediaan berkomitmen orang lain

untuk melakukan tindakan dalam rangka mewujudkan tujuan bersamayang telah disepakati.

House dan Javidan (dalam André, 2008: 295) bahwa: "the ability of individuals to influence, motivate and enable others to contribute to effectiveness and success of their organization. " individu untuk mempengaruhi, memotivasi dan memungkinkan orang lain berkontribusi terhadap kefektifan dan kesuksesan organisasinya. kepemimpinan secara luas, adalah meliputi proses mempengaruhi dalam menentukan tujuan organisasi, memotivasi perilaku pengikut untuk mencapai tujuan, mempengaruhi interprestasi mengenai peristiwa - peristiwa para pengikutnya, pengorganisasian dan aktivitas - aktivitas untuk mencapai sasaran, memelihara hubungan kerja sama dan kerja kelompok, perolehan dukungan dan kerja sama dari orang - orang di luar kelompok atau organisasi.

Menurut Hasibuan (2003:170) "Kepemimpinan adalah cara seorang pemimpin mempengaruhi perilaku bawahan agar mau bekerja sama dan bekerja secara efektif dan efisien untuk mencapai tujuan organisasi".

Kemudian Riant Nugroho (2008: 587-588), terdapat 5 (lima) karakter kepemimpinan yang unggul, yaitu karakter, kredibilitas, nilai, keteladanan, serta kemampuan memberikan dan menjadi bagian dari harapan. Selain karakteristik karaktersitik di atas, menurut Joseph (2007: 25-28) setidaknya ada sepuluh kompetensi yang perlu dimiliki oleh seorang pemimpin, yaitu:

a. Arah diri (self direction). Arah diri merupakan kemampuan untuk menyusun tujuan untuk dirinya dan melintang jalur yang mengarahkan pada tujuan dengan dedikasi pemikiran tunggal. Hal ini merupakan kunci dorongan personal dalam memimpin. Beberapa orang menyusun tujuannya tetapi tidak diikuti dengan dorongan personal. Sementara yang lainnya memulai dengan bekerja atas tujuantujuannya, tetapi mungkin tidak sampai akhir. Beberapa orang membutuhkan sentuhan yang tetap dari orang lain untuk mencapai tujuan.

b. Fleksibilitas (flexibility), yaitu kemampuan untuk mengubah dirinya sesuai dengan situasi. Esensi dari fleksibilitas mental adalah kemampuan untuk menangani situasi yang berbeda dalam cara yang berlainan, khususnya untuk menanggapi hal-hal yang baru, komplek dan situasi yang problematik.

c. Tim kerja (team work), yang merupakan kemampuan untuk bekerja bersama terhadap visi bersama. Kemampuan tersebut untuk mengarahkan individu melaksanakan tujuan organisasi. Semua anggota tim 
dalam suatu kelompok harus mengerti tujuan bersama organisasi. Tim yang baik adalah tim yang dikelola dan mengetahui bagaimana akan berhubungan dengan situasi-situasi tertentu. Setiap anggota tim memainkan peranan yang penting. Beberapa tim yang baik juga mengetahui kekuatan masing-masing anggota dan mengambil keuntungan dari kekuatan tersebut. Kemampuan kerja tim antara lain mencakup: bekerja bersama dalam suatu kelompok untuk mencapai tujuan bersama, mencapai hasil yang ingin dicapai, merayakan kesuksesan, memiliki pimpinan tim yang jelas, memiliki tujuan yang jelas, mendukung satu sama lain dalam mencapai tujuan, masingmasing anggota memiliki kemampuan untuk mempengaruhi keputusan, dan masingmasing anggota memiliki tanggung jawab personal atas kinerja dan kualitasnya.

d. Strategi (strategy). Strategi adalah kejadian suatu tindakan yang diadopsi sesudah disaring secara ekstensif melalui data-data yang tersedia dan sesudah dievaluasi dari alternatif solusi yang bervariasi. Strategi juga merupakan kemampuan untuk memahami dan menginterpretasikan informasi untuk tindakan-tindakan tertentu yang akan diimplementasikan.

e. Pengambilan keputusan (decision making). Pengambilan keputusan merupakan studi yang mengidentifikasi dan memilih alternatifalternatif yang didasarkan pada nilai dan preferensi dari pembuat keputusan. Membuat keputusan berdampak bahwa ada alternatifalternatif pilihan untuk dipertimbangkan dan dalam kasus ini tidak hanya mengidentifikasi banyak alternatif yang mungkin, tetapi juga memilih salah satu yang terbaik dan cocok dengan tujuan, kehendak, gaya hidup, nilai dan sebagainya. Pengambilan keputusan juga merupakan proses mengurangi ketidakpastian dan alternatif yang meragukan.

f. 6. Mengelola perubahan (managing change). Megelola perubahan merupakan kemampuan untuk beradaptasi terhadap perubahan skenario tanpa kehilangan keefektivan dan efisiensi. Mengelola perubahan mencakup mengelola perubahan tugas, area praktik profesional dan tubuh pengetahuan.

g. Delegasi (delegation). Delegasi adalah kesediaan untuk menugaskan tanggung jawab kepada yang lain. Delegasi merupakan fungsi manajerial yang penting untuk mengurangi beban tugas pimpinan. Delegasi membutuhkan kepercayaan yang cukup terhadap orang yang diberikan delegasi tugas.

h. Komunikasi (communication). Komunikasi adalah proses yang mana informasi melewati atau dibawa dalam berbagai bentuk. Komunikasi bisa dalam bentuk organisasi atau tim dalam sebuah organisasi. Komunikasi yang efektif tergantung pada tiga faktor, yaitu kepercayaan, emosi dan alasan.

i. Negosiasi (negotiation). Negosiasi adalah proses dimana dua pihak memecahkan perselisihan, setuju atas terjadinya suatu tindakan atau mencoba untuk memperoleh hasil yang saling menguntungkan. Kepentingan yang saling diuntungkan merupakan bagian penting dalam negosiasi dan tidak boleh hanya satu pihak saja yang diuntungkan. 
j. Kekuasaan dan pengaruh (power and influence). Kekuasaan adalah kemampuan untuk menggunakan pengaruh dalam organisasi atau individu di luar wewenang yang diturunkan dari jabatan.

\section{Kinerja Karyawan}

Menurut Simamora kinerja adalah ukuran keberhasilan organisasi dalam mencapai misinya ( Simamora, 2003). Sedangkan Shadily (2008), mengatakan kinerja atau performance adalah berdaya guna prestasi atau hasil. Kinerja merupakan catatan Outcome yang dihasilkan dari fungsi pegawai tertentu atau kegiatan yang dilakukan selama periode waktu tertentu. Kinerja suatu jabatan secara keseluruhan sama dengan jumlah (rata-rata) dari kinerja fungsi pegawai atau kegiatan yang dilakukan. Dari pengertian di atas maka dapat dikatakan bahwa kinerja itu merupakan kombinasi dari kemampuan, usaha dan kesempatan yang dapat dinilai dari hasil kerjanya yang diperoleh selama periode waktu tertentu dan meliputi elemen-elemen seperti kuantitas dari hasil, kualitas dari hasil, kehadiran dan kemampuan bekerja sama.

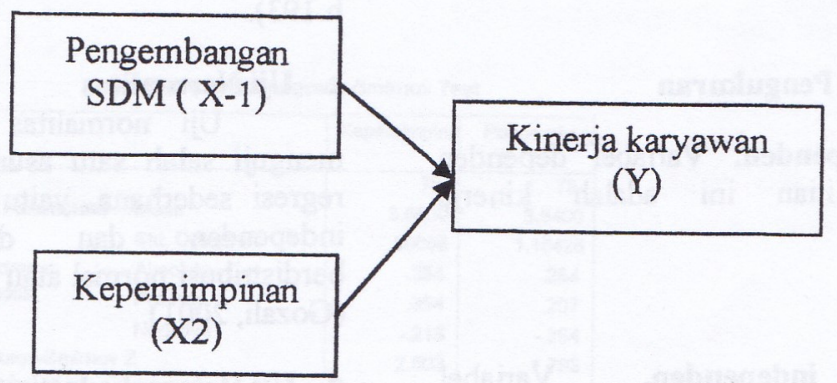

Metode Penelitian.

Dalam penelitian ini penulis
menggunakan metode pendekatan kuantitatif. Penelitian kuantitif menurut Sugiyono, (2009:15) adalah sebagai berikut : Pada hakikatnya ialah menggali data yang bersifat empirik dan terukur, serta data yang diperoleh bisa berbentuk suatu hasil jawaban dari pertanyaan yang dibuat dari kuesioner peneliti terhadap responden di lapangan. Dengan metode kuantitatif hanya dapat digali fakta - fakta yang bersifat empiric dan terukur. Fakta - fakta yang tidak tampak oleh indera akan sulit diungkapkan"Metode yang digunakan dalam penelitian ini adalah analisis deskriptif kuantitatif.

Dengan metode deskriptif kuantitatif maka akan digunakan rumusrumus yang sesuai teori sehingga dapat menjawab rumusan masalah yang ada dalam penelitian.

\section{Penentuan Sampel}

Sampel ditentukan berdasarkan teknik purposive sampling yaitu populasi yang akan dijadikan sampling adalah yang memenuhi kriteria tertentu. 
Pengertian sampel menurut Sugiyono (2012:120) menyatakan bahwa: "sampel adalah bagian dari jumlah dan karakteristik yang dimiliki oleh populasi tersebut. Bila populasi besar dan peneliti tidak mungkin mempelajari semua yang ada pada populasi, misalnya karena keterbatasan dana, tenaga dan waktu, maka peneliti dapat menggunakan sampel yang diambil dari populasi itu". Penelitian ini menggunakan metode sample probability melalui cara sample purposive random sampling yaitu metode penarikan sample probabilitas dengan cara acak sederhana dan setiap responden memiliki peluang yang sama untuk terpilih sebagian responden. Sampel dalam penelitian ini sebanyak 78 responden.

\section{Variabel dan Pengukuran}

Variabel dependen. Variabel dependen dalam penelitian ini adalah kinerja karyawan.

\section{Variabel independen. Variabel independent dalam penelitian ini adalah pengembangan SDM dan kepemimpinan}

\section{Uji Hipotesis}

\section{Pengujian instrumen penelitian menggunakan uji validitas dan uji reliabilitas dengan menggunakan bantuan program Statsitical Package of Social Science (SPSS) 21.0 sebagai berikut.}

\section{a. Uji validitas}

Untuk melakukan uji validitas dalam penelitian ini digunakan Korelasi Pearson Product Moment (Singarimbun,
1995:137). Valid tidaknya indikator (item) dari daftar pertanyaan yang diajukan, apabila koefisien korelasi dari product moment ( $r$ ) hitung $\geq r$ tabel.

\section{b. Uji Reliabilitas}

Peneliti melakukan uji reliabilitas guna untuk mengukur dari sebuah instrumen, dimana reliabilitas terhadap instrumen yang dinyatakan valid. Sedangkan instrumen yang dinyatakan tidak valid maka tidak bisa dilakukan uji reliabilitas. Dalam pengukuran reliabilitas dapat menggunakan rumus Alpha Cronbach dengan bantuan SPSS.

Adapun teknik uji reliabilitas adalah reliabilitas internal, menggunakan rumus Alpha Cronbach dalam Arikunto (1998, h. 193).

\section{c. Uji Normalitas}

Uji normalitas bertujuan untuk menguji salah satu asumsi dasar analisis regresi sederhana, yaitu variabel-variable independen dan dependen harus berdistribusi normal atau mendekati normal (Gozali, 2001).

\section{d. Uji Heteroskedastisitas}

Priyatno

mengemukakan bahwa: Heteroskedastisitas adalah keadaan dimana terjadi ketidaksamaan

varian dari residual untuk semua pengamatan pada model regresi. Uji heteroskedastisitas digunakan untuk mengetahui ada atau tidaknya ketidaksamaan varian dari residual pada model regresi. Prasyarat yang harus dipenuhi dalam model regresi adalah tidak adanya gejala heteroskedastisitas 


\section{Metode Analisis Data}

\section{Hasil Uji Reliabilitas}

Pengujian reliabilitas adalah berkaitan dengan masalah adanya kepercayaan terhadap alat test (instrumen). Suatu instrumen dapat memiliki tingkat kepercayaan yang tinggi jika hasil dari pengujian/test instrumen tersebut menunjukkan hasil yang tetap.

Rules of thumb menyarankan bahwa nilai cronbach's alpha harus lebih besar atau sama dengan 0,50 (Hair et. al 1998). Jika nilai item to total correlation yang kurang dari 0,50 , item tersebut dapat dipertahankan jika bila dieliminasi justru menurunkan cronbach's alpha (Purwanto, 2002). Jadi berdasarkan Rules of thumb terlihat bahwa uji reliabilitas konsistensi internal koefisien Croncbach's Alpha untuk semua variabel berada pada tingkat yang dapat diterima.

\section{Uji Normalitas}

Uji normalitas bertujuan untuk menguji apakah suatu data berdistribusi normal atau tidak. Penentuan normal atau tidaknya distribusi data dapat dilakukan pengujian dengan menggunakan statistik KolmogorovSmirnov. Hasil uji menunjukkan bahwa nilai Asymp. Sig. 0,074. Oleh karena nilai Asymp. Sig. lebih besar dari alpha 5 persen maka, dapat dinyatakan bahwa model uji telah memenuhi syarat normalitas data.

One-Sample Kolmogorov-Smimov Test

\begin{tabular}{|ll|r|r|}
\hline & & Kepemimpina & Pengemban \\
\hline N & & 78 & 78 \\
Normal Parameteres & Mean & 3.6600 & 3.5400 \\
& Std. Deviation & .96065 & 1.16426 \\
Most Extreme & Absolute & .354 & .254 \\
Differences & Positive & .354 & .207 \\
& Negative & -.218 & -.254 \\
Kolmogorov-Smirnov Z & 2.503 & 1.793 \\
Asymp. Sig. (2-tailed) & .074 & .073 \\
\hline a. Test distribution is Normal. & & \\
b. Calculated from data. & & \\
\end{tabular}




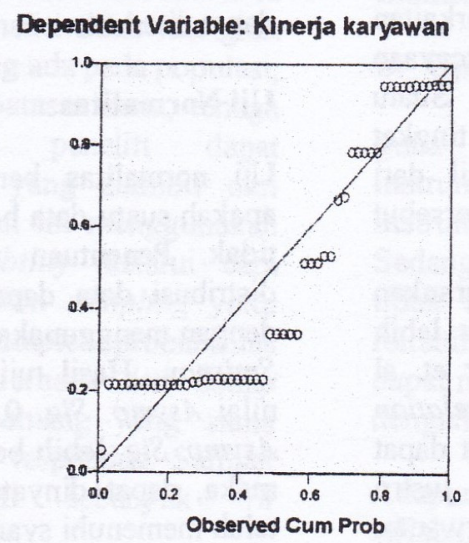

\section{Hasil Uji regresi linier.}

Analisis regresi digunakan untuk mengetahui bagaimana variabel independen mempengaruhi variabel dependen. Jika $\mathrm{X}$ adalah variabel independen dan $\mathrm{Y}$ adalah variabel dependen, maka terdapat hubungan antara variabel $\mathrm{X}$ dan $\mathrm{Y}$, di mana variasi dari $\mathrm{X}$ akan diiringi pula variasi dari $\mathrm{Y}$. dengan kata lain, variabel dari $\mathrm{Y}$ disebabkan oleh variasi dari variabel independen $X$ dan oleh variasi lainnya yang tidak diteliti.

coetresents"

\begin{tabular}{|c|c|c|c|c|c|c|}
\hline \multirow[b]{2}{*}{ todied } & & \multicolumn{2}{|c|}{$\begin{array}{l}\text { Unstandaredized } \\
\text { Conficiersts }\end{array}$} & \multirow{2}{*}{$\begin{array}{l}\text { Standardized } \\
\text { Cosficients } \\
\text { Beta }\end{array}$} & \multirow[b]{2}{*}{$t$} & \multirow[b]{2}{*}{ Sig. } \\
\hline & & $B$ & sed Enor & & & \\
\hline 1 & "Constantin & 1.658 & .983 & & 1.667 & .088 \\
\hline & Pangembangansd & 319 & .134 & .018 & 3.140 & .000 \\
\hline & Kenpontumpinan & .686 & 225 & .410 & 3.064 & .004 \\
\hline
\end{tabular}

Berdasarkan hasil pengolahan data dengan SPSS 19 menunjukkan bahwa variabel pengembangan SDM berpengaruh signifikan terhadap kinerja karyawan perusahaan. Persamaam regresi linier menunjukkan $\mathbf{Y}=1,658+0,319 \mathrm{xl}+$ $0,686 \times 2$ + e yang berarti bahwa jika Pengembangan sdm ditingkatkan 1 satuan maka akan meningkatkan kinerja karyawan sebesar 0,31 dan jika kepemimpinan ditingkatkan sebesar 1 satuan maka akan meningkatkan kinerja karyawan sebesar 0,68 . Hal ini menunjukkan bahwa kegiatan pengembangan sdm yang dilakukan perusahaan mampu memberikan pengaruh terhadap kinerja karyawan. Untuk itu perusahaan perlu terus meningkatkan pengembangan $\mathrm{sdm}$ melalui kegiatan pelatihan bagi karyawan.

Uji t parsial.

Uji $t$ dilakukan untuk menunjukkan seberapa jauh pengaruh satu variabel independen secara individual dalam menerangkan variasi variabel dependen (Ghozali, 2012 :85). Hipotesis statistik dari pengujian ini adalah : 
Jika $\mathrm{t}_{\text {hitung }}>\mathrm{t}$ tabel atau nilai sig $<0,05$ berarti Ho ditolak, Ha diterima berarti ada pengaruh antara variabel eksogen terhadap variabel endogen. Jika $t_{\text {hitung }}<t_{\text {tabel }}$ atau nilai sig $<0,05$ berarti Ho diterima berarti $\mathrm{Ha}$ ditolak berarti tidak ada pengaruh antara variabel eksogen terhadap variabel endogen.

Hasil uji hipotesis $t_{\text {hitung }}$ menunjukkan 3,140 atau $>$ dari $t_{\text {tabel }} 1,679$ yang berarti secara parsial pengembangan SDM berpengaruh terhadap kinerja karyawan. Penelitian ini sejalan dengan pendapat simamora bahwa seorang pegawai akan membutuhkan serangkaian pengetahuan, keahlian dan kemampuan yang berkembang untuk bekerja dengan baik dan suksesi posisi yang ditemui selama karirnya. Dengan adanya pelaksanaan pendidikan maka karyawan akan lebih meningkat kinerja dan pencapaian hasil kerjanya.

Uji hipotesis kedua tentang pengaruh kepemimpinan terhadap kinerja karyawan.

\section{Hasil Penelitian dan Pembahasan}

Pengaruh Pengembangan SDM terhadap kinerja karyawan.

Berdasarkan analisis data diketahui bahwa variabel pengembangan SDM berpengaruh positif dan signifikan terhadap kinerja karyawan.

\section{Pengaruh kepemimpinan terhadap} Kinerja karyawan.

Berdasarkan analisis data diketahui bahwa variabel kepemimpinan berpengaruh positif dan signifikan terhadap kinerja karyawan. Hasil uji hipotesis $t_{\text {hitung }}$ menunjukkan 3,054 atau $>$ dari $t_{\text {tabel }} 1,679$ yang berarti secara parsial kepemimpinan berpengaruh terhadap kinerja karyawan. Hasil penelitian ini menunjukkan bahwa jika manajemen memiliki model kepemimpinan yang baik akan memberikan pengaruh terhadap prestasi karyawan dalam melakukan tugas dan tanggungjawabnya. Hal ini disebabkan karena kepemimpinan merupakan dorongan utama seseorang dalam melaksanakan pekerjaan sesuai tugas dan tanggung jawabnya sebagai karyawan, juga mempunyai pengaruh yang besar terhadap semangat dan kegairahan kerja. Pengalaman menunjukkan bahwa kepemimpinan yang tidak memadai dapat menurunkan prestasi kerja, motivasi, dan kepuasan kerja karyawan atau bahkan menyebabkan karyawan yang potensial ke luar dari perusahaan. 


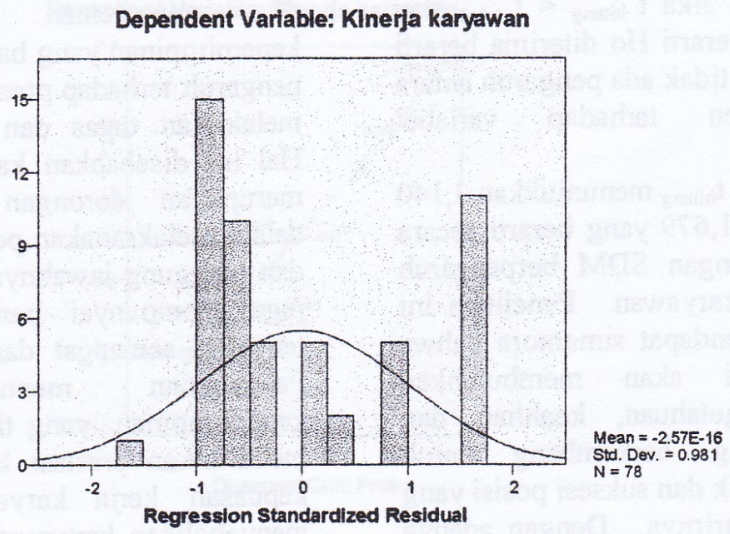

Uji Koefisien Determinasi $\left(\mathbf{R}^{2}\right)$

Koefisien Determinasi ganda ( $R$ Square atau $R^{2}$ ) digunakan untuk mengukur sumbangan dari variabel bebas ( Pengembangan SDM dan kepemimpinan ) yang diteliti terhadap variabel terikat ( Kinerja Karyawan ). Besarnya koefisien determinasi ganda $\left(\mathrm{R}^{2}\right)$ berada diantara 0 dan 1 atau $0 \mathbf{R}^{2}<1$

Semakin besar $\mathbf{R}^{2}$ dari hasil perhitungan (mendekati satu), maka dapat dikatakan bahwa sumbangan dari variabel bebas terhadap variabel terikat semakin besar. Sebaliknya jika $\mathbf{R}^{2}$ semakin kecil mendekati nol, maka dapat dikatakan bahwa sumbangan dari variabel bebas (terhadap variabel terikat semakin kecil.

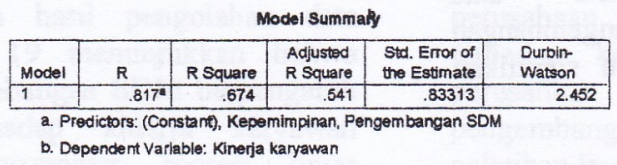

Hasil Uji determinasi $\mathrm{R}^{2}$ dapat dilihat pada table diatas menunjukan Nilai Adjusted $\mathrm{R}^{2}$ yang ditunjukan pada table diatas sebesar 0,674 artinya variabel pengembangan SDM sebagai variabel $X_{1}$, dan kepemimpinan sebagai variabel $\mathrm{X} 2$ mampu menjelaskan $67,4 \%$ variasi yang ada pada variabel kinerja karyawan (Y). sisanya sebesar $32,6 \%$ adalah variabel lain yang tidak diteliti. Hal yang mungkin adalah variabel lain yang mempengaruhi yaitu pengalaman, kepercayaan diri, tanggung jawab individu, atau iklim organisasi atau budaya organisasi dan variabel lainnya. 
Pembahasan.

Sesuai pemahaman bahwa Kinerja pegawai adalah hasil kerja secara kualitas, kuantitas, ketepatan waktu, kehadiran dan mempunyai dampak interpersonal dalam melaksanakan tugasnya sesuai dengan tanggung jawab yang diberikan kepadanya.

Pengembangan sumber daya manusia bertujuan untuk menghasilkan sumber daya manusia organisasi yang andal dan memiliki kompetensi yang sesuai dengan kebutuhan organisasi. Tujuan pengembangan sumber daya manusia pada akhirnya adalah untuk menciptakan pegawai yang memiliki kinerja yang baik dengan cara meningkatkan kemampuan mereka untuk dapat berkinerja lebih baik.

Jika kinerja pegawai sebelumnya adalah positif, maka pengembangan yang diberikan bertujuan untuk semakin meningkatkan prestasi pegawai tersebut dalam proses menapaki jenjang karir.

Hubungan dengan kepemimpinan adalah bahwa karakteristik individu akan termotivasi dan munculnya semangat kerja jika didukung oleh pimpinan. $\mathrm{Hal}$ ini menunjukkan bahwa dukungan pimpinan dapat merubah hasil kualitas kerja bawahan.

Sumber daya manusia merupakan kunci pokok yang harus diperhatikan dengan segala kebutuhannya. Sebagai kunci pokok, sumber daya manusia akan menentukan keberhasilan pelaksanaan kegiatan organisasi. Tuntutan organisasi untuk memperoleh, mengembangkan kualitas diri dan mempertahankan sumber daya manusia yang berkualitas semakin mendesak sesuai dengan dinamika lingkungan yang selalu berubah. Perubahan perlu mendapat dukungan pimpinan puncak sebagai langkah pertama yang penting untuk dilakukan. Faktor kepemimpinan berperan penting dalam mengarahkan karyawan menjadi lebih baik.

\section{Kesimpulan dan Saran.}

Kesimpulan

1. Berdasarkan hasil uji $t$ hitung $>t$ tabel maka $\mathrm{HO}_{1}$ ditolak dan $\mathrm{Ha}_{1}$ diterima, artinya Pengembangan SDM berpengaruh signifikan terhadap kinerja karyawan. Hal ini mengandung pengertian bahwa kinerja karyawan dapat dipengaruhi pengembangan SDM melalui kegiatan pelaksanaan pendidikan dan pelatihan karyawan yang diadakan secara rutin oleh perusahaan.

2. Berdasarkan hasil uji $t$ hitung $>t$ tabel maka $\mathrm{HO}_{2}$ ditolak dan $\mathrm{Ha}_{2}$ diterima, artinya kepemimpinan berpengaruh signifikan terhadap kinerja karyawan. $\mathrm{Hal}$ ini mengandung pengertian bahwa kinerja karyawan dapat dipengaruhi oleh adanya dukungan kepemimpinan terhadap kualitas kerja karyawan.

3. Penelitian ini menjawab hipotesis diawal penelitian yaitu adanya pengaruh signifikan pengembangan SDM dan kepemimpinan terhadap Kinerja karyawan.

4. Berdasarkan uji $\mathbf{R}$ Square, diketahui bahwa variabel pengembangan SDM dan kepemimpinan mampu mempengaruhi 67,4 persen Kinerja karyawan.

\section{Saran}

1. Bagi perusahaan pengembangan SDM harus terus ditingkatkan yaitu dengan pelaksanaan kegiatan diklat untuk memacu kualitas kerja karyawan. Sehingga disarankan untuk dibuat program kerja pelatihan karyawan secara terpadu.

2. Variabel penelitian yang diuji yang berhubungan kinerja karyawan diantaranya adalah pengembangan sdm dan kepemimpinan dalam rangka meningkatkan perilaku manusia dalam meningkatkan prestasi kerja. 


\section{DAFTAR PUSTAKA}

Alwi, Syafrudin. (2001). Manajemen Sumber Daya Manusia (Strategi Keunggulan Kompetitif, Edisi Pertama. Yogyakarta: FE UGM.

Aroef, Matias, (1986). Pengukuran Produktivitas Kebutuhan Mendesak Di Indonesia", Jakarta : Prisma.

Djarwanto., Pangestu, Subagyo, (1988). Statistik Induktif. Yogyakarta : BPFE.

Dessler, Garry, (1986). Manajemen Personalia Teknik dan Konsep Modern. Jakarta : Erlangga.

Ferawanti, (2005). Pengaruh Tingkat Pendidikan dan Pengalaman Kerja Terhadap Produktivitas Kerja Karyawan Bagian Keperawatan pada Rumah Sakit Ortopedi Prof. Dr. R. Soeharso Surakarta, Jurnal Ekonomi dan Manejemen, Vol 2 Tahun 2012

Flippo, Hasibuan. (2002). Manajemen Sumber Daya Manusia Cetakan ke 6. Jakarta: Bumi aksara.

Hasibuan, Malayu. (2002). Manjemen Sumber Daya Manusia. Edisi Revisi. Jakarta: Bumi Aksara Jakarta.

Handoko, T. Hani, (1995). Manajemen Personalia dan Sumber Daya Manusia.
Edisi 2. Yogyakarta : BPFE.

Nawawi, Hadari. (2011), Instrumen Penelitian Bidang Sosial. Yogyakarta : Gadjah Mada University Press.

Hedjrachman., Ranupandojo., Suad Husnan. (1992). Manajemen Personalia. Yogyakarta : BPFE.

Iqbal, M. Hasan.(2001). Metodologi Penelitian dan Aplikasinya. Jakarta : Ghalia Indonesia.

Hasibuan, Malayu. (2007). Manajemen Sumber daya Manusia, Jakarta:Bumi Aksara

Manullang, M. (2005). Dasar-dasar Manajemen, Jakarta: GMU Press.

M. Steers, Richard. (1985). Efektivitas Organisasi. Jakarta: Erlangga.

Thoha, Miftah. (2005). Manajemen Kepegawaian Sipil di Indonesia. Jakarta : Penerbit Kencana.

Notoatmodjo, Soekidjo. (2003). Pengembangan Sumber Daya Manusia. Jakarta: PT Rineka Cipta.

Prajudi, Atmosudiarjo., Moekijat. (2003). Manajemen Kepegawain Jakarta: Bumi Aksara

Siagian, Sondang P. (2006). Manajemen Sumber Daya Manusia. Jakarta : Bumi

Aksara 